\title{
PENGARUH KEPEMIMPINAN SPIRITUAL PADA WORK ENGAGEMENT DI LEMBAGA PENDIDIKAN ISLAM: PERAN KEBERMAKNAAN KERJA DAN KEANGGOTAAN SEBAGAI PEMEDIASI
}

\author{
Wahyu Saripudin \\ Departemen Manajemen Universitas Gadjah Mada \\ wahyu.saripudin@ugm.ac.id \\ Nita Sugiarta Wijaya \\ Departemen Manajemen Universitas Gadjah Mada \\ nita.sugiarta.wijaya@mail.ugm.ac.id
}

\begin{abstract}
ABSTRAK
Topik kepemimpinan spiritual terus mendapatkan perhatian dari para peneliti. Pengujian kepemimpinan spiritual telah banyak di lakukan dalam berbagai konteks. Namun demikian, pengujian peran kepemimpinan spiritual secara khusus dalam konteks staf pendidik maupun tenaga kependidikan di Lembaga Pendidikan Islam masih jarang dilakukan. Padahal konteks Lembaga Pendidikan Islam memiliki karakteristik tersendiri. Oleh karenanya, penelitian ini bertujuan untuk menguji peran kepemimpinan spiritual dalam mempengaruhi work engagement dengan dimediasi oleh rasa kebermaknaan dan keanggotaan. Penelitian ini menggunakan pendekatan kuantitatif. Proses pengumpulan data menggunakan survey dengan metode pengambilan sampel secara sengaja (purposive sampling). Data dikumpulkan dari 269 orang yang bekerja di Lembaga Pendidikan Islam yang berlokasi di Daerah Istimewa Yogyakarta. Hasil penelitian menunjukkan bahwa kepemimpinan spiritual dipengaruhi oleh inner life dan kepemimpinan spiritual berpengaruh positif signifikan pada rasa kebermaknaan kerja dan rasa keanggotaan. Lebih lanjut, rasa kebermaknaan kerja dan keanggotan hanya memiliki peran secara parsial dalam memediasi pengaruh kepemimpinan spiritual terhadap work enggagement.
\end{abstract}

Kata kunci: kepemimpinan spiritual, work engagement, spiritual well-being

\section{ABSTRACT}

The topic of spiritual leadership continues to receive attention from researchers. Spiritual Testing has been done in many contexts. However, testing the role of spiritual leadership specifically in the context of teaching staff and education personnel in Islamic Educational Institutions is still rarely done. Whereas the context of Islamic educational institutions has its own characteristics. Therefore, The aims of the study is to examine the effect of spiritual leadership on work 
engagement with the meaning of work and as a mediator. This study uses a quantitative approach with statistical data collection and processing. Collecting data used a survey with a purposive sampling method. There are 269 respondets who work in Islamic Educational Institutions located in the Special Region of Yogyakarta. The results show that leadership is influenced by inner life and spiritual leadership has a significant effect on the meaning of work and membership. Furthermore, the meaningfulness and membership has a partially mediating role from the relationship between spiritual leadership and work engagement.

Key words: spiritual leadership, work engagement, spiritual well-being

\section{PENDAHULUAN}

Saat ini berbagai organisasi termasuk Non Profit Organization (NPO) menghadapi tantangan yang sangat sulit di tengah situasi pandemi yang masih belum berakhir dan berbagai tantangan lainnya. Hal ini menuntut para pemimpin di berbagai lembaga untuk memahami betapa pentingnya kepemimpinan dalam organisasi karena memiliki pengaruh besar pada kualitas pelayanan, komitmen karyawan, dan kepuasan kerja mereka (Parry \& Sinha, 2005).

Di lembaga pendidikan para pemimpin seperti kepala madrasah/sekolah dihadapkan dengan berbagai tugas dan tantangan yang jauh lebih besar karena terbatasnya sumber daya yang dimiliki dan tuntutan untuk terus produktif dengan misi utama bukan untuk mencari keuntungan. Begitu juga Lembaga Pendidikan Islam, yang memiliki karakteristik dan keunikan sendiri, pemimpin di Lembaga Pendidikan Islam harus dapat memastikan bahwa semua anggota organisasi memiliki komitmen dan engagement dalam kinerja mengemban misi sosial dan dakwah terus berjalan dengan baik (Saripudin, 2014). Untuk itu, engagement karyawan sangatlah dibutuhkan dalam mempertahankan kinerja organisasi maupun mengemban misi sosial dalam mencerdaskan kehidupan berbangsa (Tobroni, 2010). Selain itu, angggota organisasi yang memiliki engagement yang tinggi akan sangat membantu lembaga pendidikan dalam mempertahankan dan meningkatkan performa kinerja organisasi (Bakker \& Albrecht, 2018). Karena pentingnya engagement anggota organisasi di lembaga pendidikan dibutuhkan berbagai macam pendekatan untuk meningkatkan work engagement anggota organisasi di lembaga pendidikan.

Salah satu pendekatan yang perlu dipertimbangkan adalah model kepemimpinan yang dibangun dalam lembaga pendidikan tersebut. Salah satu model kepemimpinan yang sedang mendapatkan perhatian lebih dari para peneliti adalah model kepemimpinan spiritual. Kepemimpinan spiritual adalah suatu kumpulan nilai, sikap, dan perilaku yang diperlukan untuk memotivasi diri sendiri maupun orang lain secara intrinsik, sehingga masing-masing memiliki perasaan kelangsungan hidup spiritual melalui kebermaknaan dan keanggotaan (Fry, 2003). Selain itu ditegaskan bahwa kepemimpinan spiritual memotivasi dan menginspirasi karyawan dengan visi yang transenden dan budaya perusahaan berdasarkan cinta altruistik (Fry et al., 2017).

Senada dengan itu, Tobroni (2010) menambahkan bahwa kepemimpinan spiritual adalah kepemimpinan yang membawa dimensi keduniawian kepada 
dimensi spiritual. Berdasarkan pada definisi ini, Tobroni (2010) menyamakan kepemimpinan spiritual dengan kepemimpinan berdasarakan etika keagamaan.

Menurut Kriger dan Seng, kata spiritual mengacu pada pencarian transendensi diri dan rasa keterkaitan yang menyertai dengan semua hal yang ada di dunia ini (Fry et al., 2017). Spiritualitas ini lebih pada urusan personal dalam diri seseorang, meskipun dapat pula termanifestasi dalam kelompok dan organisasi. Dari perspektif ini model kepemimpinan spiritual ini dapat inklusif atau ekslusif dari teori dan praktik agama. Hal itu karena spiritualitas menjadi dasar bagi agama-agama di dunia dan tradisi-tradisi spiritual.

Kepemimpinan spiritual, yaitu adanya kesesuaian antara nilai, sikap, perilaku, dengan nilai-nilai cinta altruistik yang telah dikembangkan dalam visi umum yang telah ditetapkan (Fry, 2003, 2008; Fry et al., 2017). Fry memformulasikan tiga komponen yang membentuk kepemimpinan spiritual, yaitu visi, keyakinan (hope/faith), dan cinta altruistik (Fry, 2003). Komponen kepemimpinan spiritual yang pertama adalah visi. Visi menjadi hal yang penting dalam mengarahkan dan memotivasi anggota organisasi/ karyawan. Adapun, definisi dari visi itu sendiri, yaitu gambaran masa depan dengan penjelasan eksplisit atau implisit mengenai mengapa orang harus berjuang untuk menciptakan masa depannya (Kotter, 1996, p. 68). Visi memiliki tiga fungsi yang penting dalam menjelaskan arah perubahan dengan penyederhanaan dan mengkoordinasikan dengan cepat dan efisien dengan banyak orang yang berbeda (Fry, 2003).

Komponenen kepemimpinan spiritual yang kedua adalah keyakinan (hope/faith). Keyakinan adalah kepastian akan hal-hal yang diharapkan adanya kepastian bahwa visi, tujuan dan misi organisasi akan terpenuhi (Fry, 2008). Ditegaskan oleh Sweeney et al dalam (Fry et al., 2017) bahwa keyakinan ini penting karena menyediakan arah jalan kehidupan dan keyakinan dan harapan bahwa perjalanan kehidupan ini akan menghasilkan kehidupan yang lebih baik.

Komponenen kepemimpinan spiritual yang ketiga adalah cinta altruistik. Cinta altruistik dalam kepemimpinan spiritual sebagai rasa keutuhan, keharmonisan, dan kesejahteraan yang dihasilkan melalui kepedulian, perhatian dan penghargaan bagi diri sendiri dan orang lain (Fry, 2008). Ditinjau dari psikologi positif bahwa cinta merupakan kekuatan untuk menyelesaikan pengaruh negatif dari emosi yang merusak seperti rasa takut dan marah (Fry, 2003; Fry et al., 2005). Pokok definisi ini adalah nilai-nilai seperti integritas, kebaikan, pengampunan, penerimaan, rasa terimakasih, kerendahan hati, keberanian, kepercayaan, loyaitas dan belas kasihan (Fry et al., 2017).

Fry mengembangkan kembali model kepemimpinan spiritual dengan memunculkan inner life sebagai sumber dari kepemimpinan spiritual (Fry et al., 2017). Inner life merupakan suatu kondisi sadar sepenuhnya pada hal yang terjadi saat ini dengan mengalihkan pengalaman yang lain, diterima sepenuhnya tanpa penilaian (Mace, 2008; Petchsawang \& McLean, 2017). Dalam kepemimpinan spiritual, inner life adalah pencarian sumber kekuatan yang menjadi daya bagi harapan dalam visi yang transeden untuk mencintai dan melayani orang lain (Fry et al., 2017). Beberapa contoh dari inner life adalah meditasi, sembahyang, praktik-praktik keagamaan, yoga, menikmati alam, dan konteks organisasi (seperti ruangan untuk berdoa dan refleksi diri) untuk 
memahami diri dan memperkuat kepercayaan, ajaran-ajaran filosofis, dan sistem sosial kemanusiaan (Fry, 2003, 2008; Fry et al., 2017).

Menurut Petchsawang \& McLean (2017) bahwa dengan menjalankan aktivitas kehidupan batin ini secara reguler, baik itu meditasi maupun sembahyang, akan meningkatkan kesadaran diri untuk fokus pada hal yang akan membuatnya menjadi lebih baik. Hal ini sesuai dengan firman Tuhan dalam AlQuran, bahwa sesungguhnya sembahyang itu akan mencegah dari perbuatan jelek dan keji dan akan mengingat keagungan kekuatan Tuhan (Q.S. Al Ankabut: 45). Dengan demikian, dapat dipahami bahwa kehidupan batin dan semua aktivtas spiritual menjadi sumber bagi kepemimpinan spiritual yang secara positif memengaruhi perkembangan harapan atau keimanan dalam visi pelayanan yang transenden bagi pemangku kepentingan dan nilai-nilai cinta altruistik (Fry, 2008). Dengan demikian, dapat dirumuskan hipotesis sebagai berikut yaitu $\mathrm{H} 1$ : Inner life berpengaruh positif pada kepemimpinan spiritual.

Kebermaknaan adalah sebuah perasaan bahwa kehidupan seseorang memiliki makna dan membuat perubahan (Fry, 2008). Orang akan menemukan makna dan tujuan hidupnya dengan membuat perubahan melalui pelayanan kepada orang lain secara profesional (Fry et al., 2017). Hal ini didorong oleh adanya kesesuaian antara tujuan dan visi organisasi dengan prinsip hidupnya. Selaras dengan Stregger, Dik, dan Duffy (2012), kebermaknaan kerja merupakan pekerjaan yang secara personal bermakna, memperoleh pertumbuhan personal, dan berkontribusi pada kebaikan umum. Kebermaknaan kerja ini sama halnya dengan persepsi orang merasakan keterpanggilan pada pekerjaannya (Steger et al., 2012). Orang yang merasakan keterpenggilan akan merasakan kepuasan hidup dan akan larut dalam pekerjaannya.

Ketika terjadi perubahan paradigma nilai-nilai dasar perusahaan maka spiritualitas menjadi aspek yang sangat penting di dalam organisasi tersebut (Mitoff et al., 2009). Peneliti lain menemukan bahwa mahasiswa yang di survey menginginkan pekerjaannya penuh makna (Allan et al., 2016). Begitu juga dengan Xie et al (2016) yang meneliti hubungan kebermaknaan kerja dan work enagement dengan sampel 832 orang karyawan Tiongkok, hasilnya menunjukkan bahwa kebermaknaan ini secara positif memiliki hubungan pada adaptabilitas karir, work enagement dan kepuasan karir dan adaptabilitas karir memediasi hubungan antara keterpanggilan dengan work enagement. Kemudian Saripudin dan Kurnia (2021) dalam penelitiannya menunjukkan bahwa spiritualitas di tempat kerja yang satu variabelnya adalah kebermaknaan kerja mempengaruhi komitmen efektif bagi karyawan generasi milenials.

Dengan kepemimpinan spiritualitas, karyawan merasa bahwa pekerjaannya memiliki makna bagi kehidupannya (Tobroni, 2010). Didukung oleh penelitian lain bahwa spiritualitas di tempat kerja menjadi komponen penting dalam membangun rasa kebermaknaan (Mitoff et al., 2009). Selain itu, salah satu dimensi pada kepemimpinan spiritual adalah visi. Dengan adanya kesamaan visi yang tidak hanya berorientasi pada materialistik tetapi adanya nilai yang diperjuangkan, maka ini tentu akan memengaruhi rasa kebermaknaan kerja karyawan. Dengan demikian, dapat dirumuskan Hipotesis 2 yaitu kepemimpinan spiritual berpengaruh positif pada kebermaknaan kerja.

Fry (2008, p. 117) mendefinisikan keanggotaan sebagai sebuah rasa ingin dipahami dan diapresiasi. Keanggotaan dapat dimaknai sebagai kebutuhan 
manusia untuk tergabung dengan komunitasnya sebagai bentuk spiritual hidup dalam hubungan dengan sesamanya. Dengan keanggotaan ini, visi akan tercipta dan orang akan membangun keselarasan baik secara individu, tim dan organisasi. Dengan itu, tentu akan mendorong komitmen organisasi, work engagement dan meningkatkan kinerja organisasi (Chen et al., 2011; Devendhiran \& Wesley, 2017; Fry, 2003; Saks, 2011). Pengaruh kepemimpinan spiritual pada keanggotaan ini dapat dipahami bahwa ketika seseorang merasakan adanya dukungan, keterbukaan informasi dan keteladanan dari pemimpin, maka hal ini akan meningkatkan keanggotaan seseorang. Dengan demikian, rumusan hipotesis yang diajukan adalah Hipotesis 3 yaitu kepemimpinan spiritual berpengaruh positif pada keanggotaan.

Islitah engagement pertama kali dikembangkan oleh Kahn untuk menggambarkan kondisi psikologi engagement dan disengagement seseorang pada pekerjaannya. Kahn menjelaskan bahwa personal engagement adalah penguasaan diri anggota organisasi terhadap peran pekerjaan mereka. Dalam engagement, orang mempekerjakan dan mengekspresikan diri secara fisik, kognitif, dan emosional selama berlangsungnya peran. Sedangkan personal disengagement berarti membuka diri dari peran kerja. Dalam melepaskan diri, orang menarik diri dan membela diri secara fisik, kognitif, dan emosional selama berlangsungnya peran (Kahn, 2017)

Work engagement adalah suatu keadaan pikiran yang positif terkait pekerjaan yang dicirikan dengan vigor, dedication dan absorption (Schaufeli et al., 2002). Terdapat tiga dimensi dari work enagement yaitu pertama semangat (vigor) direfleksikan dengan adanya keinginan untuk berupaya dalam pekerjaan, dan tetap berusaha meskipun berbagai tantangan dihadapinya. Kedua adalah dedikasi (dedication) direfleksikan dengan keterlibatan penuh dengan adanya rasa antusias terhadap pekerjaannya. Dan ketiga adalah penghayatan (absorption) direfleksikan dengan bekerja secara konsentrasi dan merasa asyik dengan pekerjaannya, sehingga waktu berlalu tidak terasa dan merasa sulit untuk lepas dari pekerjaan (Schaufeli et al., 2002).

Secara naluriah, orang akan merasakan senang dengan pencapaian yang didapatkannya, yaitu merasa hidupnya berarti. Ketika seseorang telah memaknai pekerjaanya bukan hanya sekedar kerja tetapi menjadi sebuah tanggung jawab yang akan menjadikan pribadi lebih baik dan memiliki nilai kebermanfaatan (Fry et al., 2017), maka dia akan mencurahkan dan mengeskpresikan diri dengan semangat yang tinggi, dedikasi dan menghayati apa yang dilakukannya. Hal itu senada dengan pendapatnya Saks (2011) yang menegaskan bahwa melalui spiritualitas membentuk kebermaknaan kerja dan dengan kebermaknaan kerja, maka engagement dapat dipertahankan. Didukung dengan penelitian Devendhiran dan Wesley (2017) yang menunjukkan bahwa spiritualitas tempat kerja yang di dalamnya termasuk kebermaknaan kerja akan meningkatkan level engagement karyawan, sedangkan penelitian Petchswang dan McLean (2017) menunjukkan bahwa spiritualitas kerja memediasi penuh hubungan meditasi dengan work engagement. Dengan demikian dapat dirumuskan Hipotesis 4 yaitu hubungan positif antara kepemimpinan spiritual dan work engagement dimediasi secara penuh oleh kebermaknaan kerja dan Hipotesis 5 yaitu hubungan positif antara kepemimpinan spiritual dan work engagement dimediasi secara full oleh Keanggotaan. 


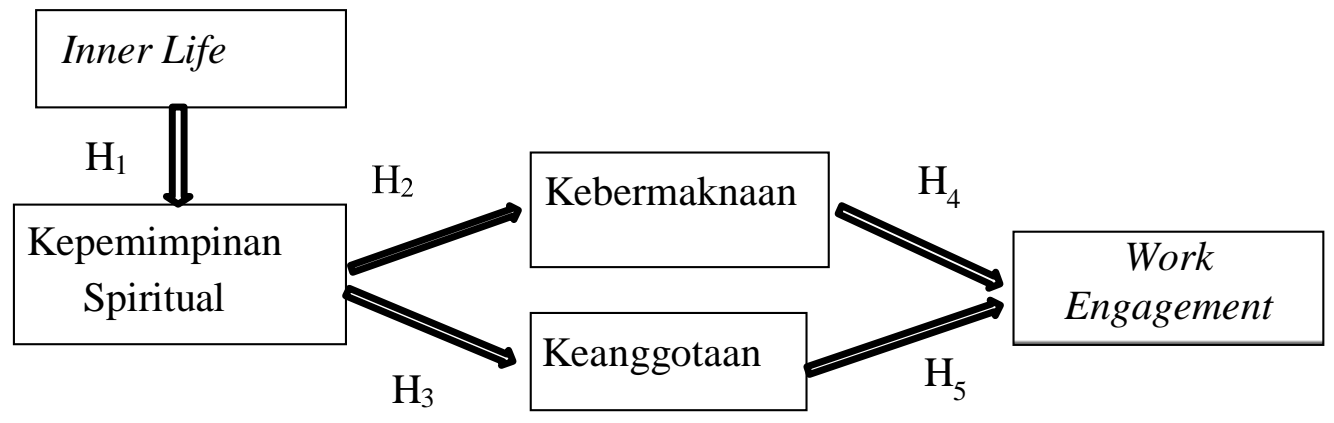

Gambar 1. Model Penelitian

(Saripudin, 2020)

Pengujian pengaruh kepemimpinan spiritual pada performa organisasi telah banyak dilakukan, beberapa di antaranya Saks (2006), Devendhiran \& Wesley (2017) dan Saripudin \& Rosari (2019). Namun demikian, penelitian empiris yang menguji peran spiritual leadership dalam konteks lembaga pendidikan masih sangat terbatas. Penelitian Saripudin \& Rosari (2019) yang dilakukan dengan konteks NPO di rumah sakit menyarankan untuk penelitian selanjutnya pengujian kepemimpinan spiritual dalam konteks NPO yang lain seperti lembaga pendidikan. Oleh karenanya, penelitian ini termotivasi untuk menguji apakah spiritual leadership model yang diidentifikasi oleh Fry (2017) berpengaruh pada work engagement di lembaga pendidikan.

Terdapat berbagai bukti empiris yang mendukung bahwa kepemimpinan spiritual memiliki pengaruh pada work engagement. Penelitian Akingbola \& van den Berg (2019) dengan konteks non profit organisasi di Kanada menunjukkan bahwa work engagement karyawan sangat tergantung pada kesesuaian nilai di organisasi tersebut. Kesesuaian nilai termasuk di dalamnya adalah spiritualitas di tempat kerja yang mana Saks (2006) dan Devendhiran and Wesley (2017) menemukan bahwa spiritualitas di tempat kerja berpengaruh signifikan pada employee engagement. Penelitian lain yang menunjukkan bahwa kepemimpinan spiritual memiliki pengaruh pada dampak perilaku di antaranya Fry et al. (2016) menemukan bahwa kepemimpinan spiritual memiliki pengaruh positif pada komitmen organisasional, produktivitas unit, dan kepuasan kerja dengan di mediasi oleh spiritual well being. Selanjutnya, penelitian Hunsaker (2017) menemukan bahwa kepemimpinan spiritual memiliki pengaruh positif signifikan juga pada partisipasi karyawan dalam perilaku kewargaan organisasional dengan self-determination sebagai pemediasi.

Dari beberapa bukti empiris terkait pengaruh kepemipinan spiritual pada work engagement, maka penelitian ini berkontribusi pada literatur yang ada dengan menawarkan konteks yang berbeda dan memberikan pemahaman lebih lanjut terkait hubungan kepempinan spiritual dan dampak perilaku di dalam konteks Lembaga Pendidikan Islam. 


\section{METODE}

Penelitian ini menggunakan pendekatan kuantitatif dengan memanfaatkan data yang diambil dengan menggunakan survey. Metode survey yang digunakan adalah purposive sampling dengan menetapkan kriteria tertentu bagi responden yang dapat mengisi survey tersebut. Pada penelitian ini, kuesioner disebarkan kepada tenaga kependidikan dan pendidik yang bekerja di Lembaga Pendidikan Islam dikhususkan di lembaga pendidikan formal seperti madrasah yang berada di wilayah Daerah Istimewa Yogyakarta. Responden mengisi jawaban dengan opsi jawaban yang telah diberikan baik menggunakan kuesioner yang dicetak maupun secara online dengan menggunakan google form. Purposive sampling yang dimaksud, yaitu menentukan kriteria responden. Dalam hal ini kriteria sampel yang ditentukan adalah tenaga pendidik atau tenaga kependidikan yang berinteraksi langsung dengan kepala madrasah dan telah bekerja minimal satu tahun. Penyebaran kuesioner dilakukan selama enam bulan dari Juli sampai Desember 2020. Terdapat 300 respons dari penyebaran kuesioner tersebut. Namun hanya 269 kuesioner yang dapat diolah dengan karakteristik responden ditunjukkan pada table berikut.

Tabel 1. Karakteristik Responden

\begin{tabular}{|c|c|c|c|c|}
\hline No & & Karakteristik & Jumlah & Persentase \\
\hline \multirow[t]{2}{*}{1.} & \multirow[t]{2}{*}{ Jenis kelamin } & Laki-laki & 97 & $36,05 \%$ \\
\hline & & Perempuan & 172 & $63,95 \%$ \\
\hline & \multirow[t]{4}{*}{ Usia } & 20 - 30 tahun & 128 & $47,58 \%$ \\
\hline & & 31 - 40 tahun & 98 & $36,43 \%$ \\
\hline & & $41-50$ tahun & 43 & $15,98 \%$ \\
\hline & & Di atas 50 tahun & 0 & $0 \%$ \\
\hline \multirow[t]{3}{*}{3.} & \multirow[t]{3}{*}{ Pendidikan } & Master & 13 & $4,83 \%$ \\
\hline & & Sarjana & 209 & $77,69 \%$ \\
\hline & & Diploma I/II/III & 47 & $17,47 \%$ \\
\hline \multirow[t]{4}{*}{4} & \multirow[t]{4}{*}{ Asal Lembaga } & Madrasah Ibtidayah & 39 & $14,49 \%$ \\
\hline & & Madrash Tsnawiyyah & 92 & $34,20 \%$ \\
\hline & & Madrasah Aliyyah & 85 & $31,59 \%$ \\
\hline & & Lainnya (Islam Terpadu) & 53 & $19,7 \%$ \\
\hline & \multirow[t]{2}{*}{ Jenis pekerjaan } & Pendidik & 194 & $72,11 \%$ \\
\hline & & Tenaga kependidikan & 75 & $27,88 \%$ \\
\hline
\end{tabular}

Penelitian ini menggunakan lima variabel, yaitu inner life, kepemimpinan spiritual, kebermaknaan kerja, keangotaan, dan work engagement. Responden memilih jawaban dengan menggunakan pengukuran 5 tipe Skala Likert dengan 
kategori SS (Sangat Setuju), S (Setuju), N (Netral), TS (Tidak Setuju), dan STS (Sangat Tidak Setuju).

Untuk menilai sejauh mana kuesioner dapat mengukur apa yang sebenarnya ingin diukur maka dibutuhkan uji validitas (Cooper \& Schindler, 2014). Pengujian dalam penelitian ini termasuk ke dalam uji validitas isi, konvergen, dan diskriminan. Validitas isi dari suatu instrumen pengukuran merupakan tingkat sejauh mana instrumen tersebut memberikan cakupan yang memadai dari pernyataan-pernyataan investigatif yang mengarahkan penelitian. Validitas isi pada penelitian ini mencakup face validity, yaitu dengan mengajukan butir-butir pernyataan kuesioner yang telah diterjemahkan dari Bahasa Inggris ke dalam Bahasa Indonesia dan dilakukan uji coba pemahaman kuesioner kepada beberapa orang sebelum kuesioner disebarkan.

Pengujian reliabilitas bertujuan mengukur keakuratan, kecermatan, dan kekonsistenan dari suatu instrument (Cooper \& Schindler, 2014). Kehandalan suatu kuesioner dapat dilihat Ketika jawaban seseorang tanpa bias, konsisten dari waktu ke waktu. Penelitian ini menggunakan konsistensi internal pengukuran Cronbach alpha untuk melihat reliabilitas kuesioner. Kategorisasi reliabilitas terdapat tiga jenis yaitu Cronbach alpha bernilai 0,80-1,00 maka reliabilitas kuesioner baik, Cronbach alpha bernilai 0,60- 0,79 maka reliabilitas kuesioner dapat diterima, Cronbach alpha bernilai kurang dari 0,60 maka reliabilitas kuesioner buruk (Ghozali, 2017).

Pengujian hipotesis menggunakan analisis jalur. Hal ini karena penelitian menguji hubungan kausal antara dua variabel atau lebih dengan berdasarkan persamaan linear. Penggunaan analisis jalur jika menguji persamaan regresi yang memiliki beberapa variabel eksogen dan endogen secara bersamaan sehingga memungkinkan pengujian terhadap variabel mediasi. Selain itu, analisis jalur menggunakan Structural Equation Models (SEM) ini juga dapat mengukur hubungan langsung antar variabel dalam model maupun hubungan tidak langsung antar variabel dalam model yang dapat diukur maupun tidak dapat dikur. Oleh karenanya, penelitian ini pun menggunakan analisis jalur dengan SEM dengan alasan terdapat hubungan antar variabel yang kompleks, ada variabel yang tidak dapat di observasi dan ingin menguji secara keseluruhan.

Analisis terkait hubungan structural model dapat dilakukan ketika kirteria goodness of fit dari model structural yang diestimasi sudah terpenuhi. Nilai regresion weights menunjukkan hubungan antar konstruk dalam hipotesis. Hipotesis didukung jika memiliki nilai critical ratio (C.R) lebih besar dari nilai standart error (S.E) pada probabilitas (p) kurang dari 0,05. Sebaliknya, hipotesis ditolak jika memiliki nilai critical ratio (C.R) lebih besar dari nilai standart error (S.E) pada probabilitas (p) lebih dari 0,05 (Hair et al., 2010).

\section{HASIL DAN PEMBAHASAN}

Pada tahap pertama analisis data dilakukan analisis model pengukuran melalui analisis faktor konfirmatori. Analisis model pengukuran terdiri dari uji validitas dan uji reliabilitas. Hasil uji validitas dapat dilihat dari nilai outer loading dan rata-rata varians diekstrak (AVE) untuk uji validitas konvergen

Tabel 2. Hasil Nilai Outer Loading 


\begin{tabular}{|c|c|c|c|c|c|}
\hline Variabel & $\begin{array}{l}\text { Kebermak- } \\
\text { naan }\end{array}$ & $\begin{array}{c}\text { Inner } \\
\text { Life }\end{array}$ & $\begin{array}{l}\text { Keang- } \\
\text { gotaan }\end{array}$ & $\begin{array}{c}\text { Kepemimpi- } \\
\text { nan } \\
\text { Spiritual }\end{array}$ & $\begin{array}{c}\text { Work } \\
\text { Enggage- } \\
\text { ment }\end{array}$ \\
\hline CintaAltruistik5 & & & & 0.743 & \\
\hline CintaAltruistik2 & 0.904 & & & & \\
\hline CintaAltruistik5 & 0.858 & & & & \\
\hline Harapan2 & & & & 0.794 & \\
\hline Harapan 3 & & & & 0.794 & \\
\hline Harapan 4 & & & & 0.842 & \\
\hline Harapan 1 & & & & 0.736 & \\
\hline InnerLife3 & & 0.871 & & & \\
\hline InnerLife4 & & 0.859 & & & \\
\hline Visi4 & & & & 0.799 & \\
\hline Visi1 & & & & 0.802 & \\
\hline Kebermaknaan3 & 0.919 & & & & \\
\hline Keanggotaan2 & & & 0.824 & & \\
\hline Keanggotaan 3 & & & 0.848 & & \\
\hline Keanggotaan 4 & & & 0.824 & & \\
\hline WorkEnggagement15 & & & & & 0.795 \\
\hline WorkEnggagement 4 & & & & & 0.819 \\
\hline WorkEnggagement 5 & & & & & 0.811 \\
\hline WorkEnggagement 7 & & & & & 0.789 \\
\hline
\end{tabular}

(Saripudin, 2020)

Berdasarkan hasil tabel di atas menunjukkan bahwa indikator telah memenuhi ketentuan outer loading. Kemudian berikutnya adalah Tabel 3 akan menyajikan data terkait nilai AVE.

Tabel 3. Nilai AVE (Average Variance Extracted)

\begin{tabular}{lc}
\hline \multicolumn{1}{c}{ Variabel } & Rata-rata Varians Diekstrak (AVE) \\
\hline Kebermaknaan Kerja & 0.799 \\
\hline Inner Life & 0.748 \\
\hline Keanggotaan & 0.692 \\
\hline Work Enggagement & 0.646
\end{tabular}

(Saripudin, 2020)

Berdasarkan hasil nilai AVE (Average Variance Extracted) ternyata seluruh variabel memiliki nilai AVE di atas 0,5 sehingga seluruh variabel laten dapat dinyatakan valid sebagai alat ukur.

Tabel 4. Hasil Kriteria Fornell-Lacker 


\begin{tabular}{llllll}
\hline & Calling & $\begin{array}{c}\text { Inner } \\
\text { Life }\end{array}$ & Membership & $\begin{array}{c}\text { Spiritual } \\
\text { Leadership }\end{array}$ & $\begin{array}{c}\text { Work } \\
\text { Enggage- } \\
\text { ment }\end{array}$ \\
\hline Calling & 0.894 & & & & \\
\hline Inner Life & 0.733 & 0.865 & & & \\
\hline Membership & 0.632 & 0.579 & 0.832 & & \\
\hline $\begin{array}{l}\text { Spiritual } \\
\text { Leadership }\end{array}$ & 0.68 & 0.684 & 0.739 & & 0.804 \\
\hline $\begin{array}{l}\text { Work } \\
\text { Enggagement }\end{array}$ & 0.663 & 0.69 & 0.523 & 0.726 & \\
\hline
\end{tabular}

(Saripudin, 2020)

Tabel 5. Hasil Nilai Cross Loading

\begin{tabular}{llllll}
\hline & Calling & $\begin{array}{c}\text { Inner } \\
\text { Life }\end{array}$ & $\begin{array}{c}\text { Member- } \\
\text { ship }\end{array}$ & $\begin{array}{c}\text { Spiritual } \\
\text { Leader- } \\
\text { ship }\end{array}$ & $\begin{array}{c}\text { Work } \\
\text { Enggage- } \\
\text { ment }\end{array}$ \\
\hline Harapan4 & 0.552 & 0.593 & 0.598 & 0.842 & 0.639 \\
\hline Visi1 & 0.524 & 0.582 & 0.544 & 0.802 & 0.62 \\
\hline Visi4 & 0.583 & 0.53 & 0.572 & 0.799 & 0.577 \\
\hline Harapan3 & 0.581 & 0.538 & 0.53 & 0.794 & 0.6 \\
\hline Harapan2 & 0.543 & 0.539 & 0.546 & 0.794 & 0.618 \\
\hline CintaAltruistik5 & 0.495 & 0.47 & 0.705 & 0.743 & 0.427 \\
\hline Harapan1 & 0.505 & 0.485 & 0.583 & 0.736 & 0.506 \\
\hline Kebermaknaan3 & 0.919 & 0.664 & 0.569 & 0.638 & 0.61 \\
\hline Keanggotaan2 & 0.55 & 0.409 & 0.824 & 0.637 & 0.416 \\
\hline Workenggagement7 & 0.63 & 0.626 & 0.421 & 0.626 & 0.789 \\
\hline Kebermaknaan2 & 0.904 & 0.739 & 0.583 & 0.624 & 0.648 \\
\hline Keanggotaan3 & 0.536 & 0.535 & 0.848 & 0.609 & 0.477 \\
\hline Innerlife3 & 0.617 & 0.871 & 0.508 & 0.604 & 0.563 \\
\hline Keanggotaan 4 & 0.49 & 0.501 & 0.824 & 0.598 & 0.411 \\
\hline Workenggagement15 & 0.493 & 0.479 & 0.405 & 0.58 & 0.795 \\
\hline InnerLife4 & 0.652 & 0.859 & 0.493 & 0.579 & 0.632 \\
\hline Workenggagement 5 & 0.496 & 0.57 & 0.432 & 0.571 & 0.811 \\
\hline Kebermaknaan5 & 0.858 & 0.551 & 0.542 & 0.558 & 0.51 \\
\hline Workenggagement 4 & 0.493 & 0.527 & 0.422 & 0.544 & 0.819 \\
\hline & & & & & $(S a r i p u d i n$ \\
\hline
\end{tabular}

(Saripudin, 2020) 
Selanjutnya adalah tahap uji validitas diskriminan. Uji ini dapat dilihat dari hasil kriteria Fornell-Lacker dan cross loading. Berdasarkan hasil kriteria FornellLacker, apabila korelasi kuadrat suatu konstruk laten bernilai lebih besar daripada korelasi kuadrat konstruk laten tersebut dengan konstruk lain, maka dapat disimpulkan bahwa masing-masing konstruk di atas memiliki validitas diskriminan yang memuaskan berdasarkan kriteria. Selain itu, berdasarkan hasil cross loading di atas, semua indikator telah memenuhi syarat validitas diskriminan.

Tabel 6. Hasil Nilai Cronbach Alpha

\begin{tabular}{lc}
\hline \multicolumn{1}{c}{ Variabel } & Cronbach's Alpha \\
\hline Kebermaknaan & 0.874 \\
\hline Inner Life & 0.664 \\
\hline Keanggotaan & 0.778 \\
\hline Work Enggagement & 0.818 \\
\hline
\end{tabular}

(Saripudin, 2020)

Berdasarkan uji reliabilitas yang dapat dilihat dari output cronbach's alpha, seluruh variabel dapat dikatakan reliabel/baik sebagai alat ukur, kecuali variabel inner life. Hal ini karena variabel inner life memiliki cronbach's alpha $<0,7$ yaitu 0,664 . Meskipun begitu variabel inner life tetap diterima karena nilai 0,664 dapat digolongkan sebagai alat ukur yang dapat diterima.

Tabel 7. Hasil Analisis Jalur

\begin{tabular}{|c|c|c|c|}
\hline & $\begin{array}{l}\text { Sampel } \\
\text { Asli (0) }\end{array}$ & $\begin{array}{l}\mathbf{P} \\
\text { Values }\end{array}$ & Keterangan \\
\hline Inner Life -> Kepemimpinan Spiritual & 0.673 & 0.000 & Signifikan \\
\hline $\begin{array}{l}\text { Kepemimpinan Spiritual -> } \\
\text { Keanggotaan }\end{array}$ & 0.670 & 0.000 & Signifikan \\
\hline $\begin{array}{l}\text { Kepemimpinan Spiritual -> } \\
\text { Kebermaknaan Kerja }\end{array}$ & 0.678 & 0.000 & Signifikan \\
\hline $\begin{array}{l}\text { Kebermaknaan Kerja-> Work } \\
\text { Enggagement }\end{array}$ & 0.555 & 0.000 & Signifikan \\
\hline Keanggotaan -> Work Enggagement & 0.173 & 0.011 & Signifikan \\
\hline
\end{tabular}




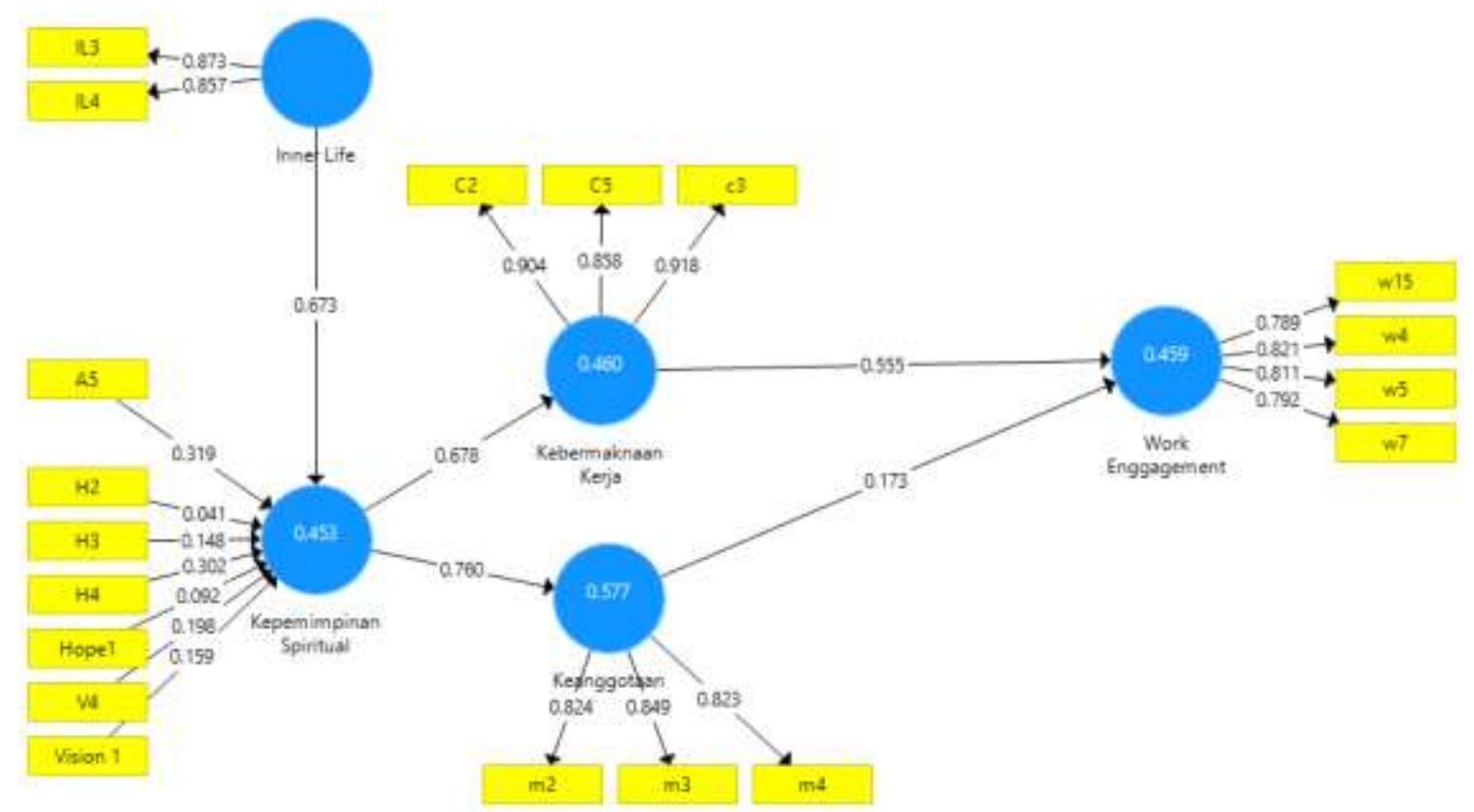

Gambar 2. Output Model Diagram

(Saripudin, 2020)

Hasil analisis jalur pada Tabel 7 dan Gambar 2, hipotesis 1 untuk hubungan inner life terhadap kepemimpinan spiritual didapatkan koefisien jalur bernilai 0,673 dan $p 0,000$. Hal ini menunjukkan bahwa inner life berpengaruh positif dan signifikan pada kepemimpinan spiritual. Semakin tinggi praktik spiritual yang dilakukan individu akan meningkatkan level kepemimpinan spiritual pada level individu tersebut. Hasil analisis jalur ini membuktikan bahwa hipotesis 1 dalam penelitian ini diterima.

Pada Tabel 7 dan Gambar 2, hasil analisis jalur di atas menunjukkan bahwa pengaruh kepemimpinan spiritual terhadap kebermaknaan kerja bernilai positif dan signifikan pada 0,678 p 0,000. Hal ini menunjukkan bahwa kenaikan kepemimpinan spiritual di level individu maupun organisasi secara signifikan dapat meningkatkan rasa kebermaknaan kerja pada karyawan dan organisasi. Hasil analisis jalur ini membuktikan bahwa hipotesis 2 penelitian ini dapat diterima.

Berdasarkan Tabel 7 dan Gambar 2, hasil analisis jalur di atas menunjukkan bahwa nilai koefisien jalur pengaruh kepemimpinan spiritual terhadap keanggotaan bernilai positif dan signifikan pada 0,760 p 0,000. Hal ini menunjukkan bahwa praktik kepemimpinan spiritual dapat meningkatkan rasa keanggotaan karyawan terhadap organisasi di tempat mereka bekerja. Oleh karena itu, hipotesis 3 penelitian ini dapat diterima. 
Tabel 8. Hasil Uji Pengaruh Tidak Langsung Spesifik

\begin{tabular}{llll}
\hline & $\begin{array}{l}\text { Sampel } \\
\text { Asli (0) }\end{array}$ & P Values & Ket \\
\hline $\begin{array}{l}\text { Kepemimpinan Spiritual-> } \\
\text { Kebermaknaan kerja }->\text { Work }\end{array}$ & 0.371 & 0.000 & Signifikan \\
Enggagament & & & \\
\hline $\begin{array}{l}\text { Kepemimpinan Spiritual-> Keanggotaan } \\
\rightarrow \text { Work Enggagement }\end{array}$ & 0.136 & 0.014 & Signifikan \\
\hline
\end{tabular}

(Saripudin, 2020)

Tabel 9. Hasil Uji Pengaruh Langsung Spesifik

\begin{tabular}{llll}
\hline & Sampel & P & Ket \\
& Asli (0) & Values & \\
\hline $\begin{array}{l}\text { Kepemimpinan Spiritual-> Work } \\
\text { Enggagament }\end{array}$ & 0.584 & 0.000 & Signifikan \\
\hline
\end{tabular}

Berdasarkan hasil uji pengaruh tidak langsung spesifik pada Tabel 8 , dapat diketahui bahwa hubungan kepemimpinan spiritual terhadap work enggagement melalui kebermaknaan kerja ternyata signifikan. Hal ini ditandai dengan nilai $p$ value uji pengaruh tidak langsung bernilai 0,000. Di lain sisi, hasil pengaruh langsung kepemimpinan spiritual terhadap work enggagement ternyata juga bernilai positif signifikan. Berdasarkan hasil analisis pengaruh hubungan langsung dan tidak langsung di atas, maka kebermaknaan kerja memediasi secara parsial pengaruh hubungan kepemimpinan spiritual terhadap work enggagement sehingga hipotesis 4 ditolak.

Berdasarkan hasil uji pengaruh tidak langsung kepemimpinan spiritual terhadap work enggagement melalui keanggotaan pada Tabel 9, didapatkan nilai $p$ value 0,014 . Hasil ini menunjukkan bahwa pengaruh hubungannya signifikan. Namun, hasil pengaruh langsung kepemimpinan spiritual terhadap work enggagement juga signifikan. Oleh karena itu, maka variabel keanggotaan memediasi pengaruh kepemimpinan spiritual terhadap work enggagement secara parsial dan hipotesis 5 tertolak.

\section{SIMPULAN}

Berdasarkan penjelasan di atas, maka dapat disimpulkan bahwa inner life atau kehidupan batin seseorang berpengaruh positif pada kepemimpinan spiritual. Selanjutnya kepemimpinan spiritual dengan cinta altruistik, visi dan harapan berpengaruh positif signifikan terhadap kebermaknaan kerja dan keanggotaan. Hal ini menunjukkan bahwa dengan kepemimpinan spiritual staf di Lembaga Pendidikan Islam baik guru maupun tenaga kependidikan akan merasakan kebermaknaan dalam pekerjaannya dan merasakan bahwa mereka merasa menjadi bagian dari kelompok tersebut. Namun demikian, 
kebermaknaan kerja dan keanggotaan ini hanya memiliki peran mediasai parsial pengaruh antara kepemimpinan spiritual terhadap work enggagement. Hal ini karena pengaruh langsung dari kepemimpinan spiritual terhadap work engagement berpengaruh positif signifikan. Dengan demikian dapat dipahami bahwa kepemimpinan spiritual dengan visi yang diciptakannya, harapan kuat yang dipegang teguhnya dan cinta altruistik yang ditunjukkannya dapat secara langsung meningkatkan work engagement staff di Lembaga Pendikan Islam tersebut.

Oleh karena itu, berdasarkan kesimpulan tersebut dapat dipahami implikasi praktis maupun teoritis. Hasil penelitian ini dapat dijadikan pertimbangan bagi pihak manajemen Lembaga Pendidikan Islam untuk menyusun kebijakan dalam rangka menciptakan iklim positif pada lingkungan kerja sehingga pendidik maupun tenaga kependidikan merasa bahwa apa yang dikerjakannya selama ini memiliki kebermaknaan bagi hidupnya dan menjadi bagian dari organisasi. Iklim kerja positif ini akan mendorong para dapat memberikan karyawan berkontribusi pada lingkungan pekerjaan secara sukarela, sehingga tingkat kualitas pekerjaan sangat baik, bahkan menghasilkan kualitas melebihi target yang sudah ditentukan. Oleh karena itu, langkah konkrit pemimpin organisasi dapat dilakukan dengan memberikan kebebasan untuk menjalankan praktik spiritual, membudayakan rasa tolong menolong dan rasa optimisme dengan memotivasi anggota seluruh staf untuk mencapai cita-cita organisasi.

\section{REFERENSI}

Akingbola, K., \& van den Berg, H. A. (2019). Antecedents, Consequences, and Context of Employee Engagement in Nonprofit Organizations. Review of Public Personnel Administration, 39(1), 46-74.

https://doi.org/10.1177/0734371X16684910

Allan, B. A., Owens, R. L., \& Duffy, R. D. (2016). Generation Me? Exploring Meaningful Work in College Students and Career Conselors. Journal of Career Development, 1 (7 September). https://doi.org/10.1177/0894845316667599

Bakker, A. B., \& Albrecht, S. (2018). Work Engagement: Current Trends. Career Development International, 23(1), 4-11. https://doi.org/10.1108/CDI-112017-0207

Chen, C. Y., Yang, C. Y., \& Li, C. I. (2011). Spiritual Leadership, Follower Mediators, and Organizational Outcomes: Evidence From Three Industries Across TwoMajor Chinese Societies. Journal of Applied Social Psychology, 42(4), 890-938. https://doi.org/10.1111/j.1559-1816.2011.00834.x

Cooper, D. R., \& Schindler, P. S. (2014). Business Research Methods. McGraw Hill/Irwin.

Devendhiran, S., \& Wesley, R. (2017). Devendhiran, S. dan Wesley. Development and Learning in Organizations, 31(5), 9-13. 
https://doi.org/10.1108/DLO-08-2016-0070

Fry, L. W. (2003). Toward a Theory of Spiritual Leadership. The Leadership Quarterly, 14(6), 693-727. https://doi.org/10.1016/j.leaqua.2003.09.001

Fry, L. W. (2008). Spiritual Leadership: State of the Art and Future Directions for Theory, Research, and Practice. Spirituality in Business, January 2008, 106124. https://doi.org/10.1057/9780230611887_7

Fry, L. W., Latham, J. R., Clinebell, S. K., \& Krahnke, K. (2017). Spiritual Leadership as A Model for Performance Exellence: A Study of Baldrige Award Recipients. Journal of Management, Spirituality \& Religian, 14(1), $22-$ 47. https://doi.org/10.1080/14766086.2016.1202130

Fry, L. W., Vitucci, S., \& Cedillo, M. (2005). Spiritual Leadership and Army Transformation: Theory, Measurement, and Establishing A Baseline. The Leadership Quarterly, 16(5), 835-862.

https://doi.org/10.1016/j.leaqua.2005.07.012

Ghozali, I. (2017). Model Persamaan Struktural Konsep dan Aplikasi dengan Program Amos 24. Badan Penerbit Universitas Diponogoro.

Hair, J. R., Black, W. C., Babin, B. J., \& Anderson, R. E. (2010). Multivariate Data Analysis. Pearson.

Hunsaker, W. D. (2017). Spiritual leadership and organizational citizenship behavior: Exploring the conditional effects of self-determination and Confucian mindset. International Journal of Business and Society, 18(3), 485-502. https://doi.org/10.33736/ijbs.3141.2017

Kahn, W. A. (2017). Psychological Conditions of Personal Engagement and Disengagement at Work. Academy of Management Journal, 33(4). https://doi.org/10.5465/256287

Kotter, J. P. (1996). Leading Change. Harvard Business School Press.

Mace, C. (2008). Mindfulness and Mental Health: Therapy, Theory and Science. Routledge.

Mitoff, I. I., Denton, E. A., \& Alpaslan, C. (2009). A Spiritual Audit of Corporate America: Ten Years Later Spirituality and Attachment Theory. Journal of Management, Spiritual \& Religion, 1, 27-41.

https://doi.org/10.1080/14766080802648698

Parry, K. W., \& Sinha, P. N. (2005). Researching the Trainability of Transformational Organizational Leadership. Human Resource Development International, 8(2), 165-183. https://doi.org/10.1080/13678860500100186

Petchsawang, P., \& McLean, G. N. (2017). Workplace Spirituality, Mindfulness Meditation, and Work Engagement. Journal of Management, Spirituality and Religion, 14(3), 216-244. https://doi.org/10.1080/14766086.2017.1291360

Saks, A. M. (2006). Antecedents and Consequences of Employee Engagement. Journal of Managerial Psychology, 21(7), 600-619. https://doi.org/10.1108/02683940610690169

Saks, A. M. (2011). Workplace Spirituality And Employee Engagement. Journal of Management, Spirituality \& Religion, 8(4), 317-340. https://doi.org/10.1080/14766086.2011.630170

Saripudin, W. (2014). Manajemen Lembaga Pendidikan Islam: Studi Historis Pengelolaan Lembaga Pendidikan Pada Masa Abbasiyah [UIN Sunan Gunung Djati Bandung]. http://digilib.uinsgd.ac.id/id/eprint/17761 
Saripudin, W., \& Kurnia, A. (2021). Do Workplace Spirituality and Emotional Intelligence Have A Role in Enhancing Affective Commitment for Millenials? Management and Sustainable Development Journal, 3(2), 29-57. https://doi.org/10.46229/msdj.v3i2.315

Saripudin, W., \& Rosari, R. (2019). Does Spiritual Leadership Model Enchance Work Engagement? Empirical Evidence From an Islamic Hospital in Yogyakarta. Journal of Leadership Organization, 1(2), 112-133. https://doi.org/10.22146/jlo.45520

Schaufeli, W. B., Salanova, M., González-romá, V., \& Bakker, A. B. (2002). The Measurement of Engagement and Burnout: A Two Sample Confirmatory Factor Analytic Approach. Journal of Happiness Studies, 3(1), 71-92. https://doi.org/10.1023/A:1015630930326

Steger, M., Dik, B. J., \& Duffy, R. D. (2012). Measuring meaningful work: The Work and Meaning Inventory (WAMI). Journal of Career Assessment, 20(3), 322-337. https://doi.org/10.1177/1069072711436160

Tobroni. (2010). The Spiritual Leadership: Pengefektivan Organisasi Noble Industry Melalui Prinsip-Prinsip Spiritual Etis (UMM Press).

Xie, B., Xia, M., Xin, X., \& Zhou, W. (2016). Linking Calling to Work Engagement and Subjective Career Success: The Perspective of Career Construction Theory. Journal of Vocational Behavior, 94, 70-78.

https://doi.org/10.1016/j.jvb.2016.02.011 